\title{
Teachers' Professional Development Needs and the Systems That Meet Them
}

\author{
Mahmut Sağır \\ Department of Educational Sciences, Faculty of Education, Kahramanmaras Sutcu Imam University, \\ Kahramanmaraş, Turkey \\ Email: msagir@ksu.edu.tr
}

Received 17 July 2014; revised 2 August 2014; accepted 21 August 2014

Copyright (C) 2014 by author and Scientific Research Publishing Inc.

This work is licensed under the Creative Commons Attribution International License (CC BY). http://creativecommons.org/licenses/by/4.0/

(c) (i) Open Access

\begin{abstract}
The purpose of this study was to identify professional development needs of primary and secondary school teachers and to present their views on the systems that meet those needs. The research model utilized in the study was the mixed model type. Findings related to identification of teachers' professional development needs were collected through quantitative methods whereas findings related to systems that meet those needs were collected qualitatively. The study utilized survey model since it identified teachers' professional development needs and investigated the systems that meet those needs. The part of the study related to identification of teachers' professional development needs was quantitative and the section that investigated the systems that met professional development needs was qualitative. Data regarding the quantitative part of the study was collected with a data collection tool composed of 34 items prepared by the researcher and the data regarding the qualitative part of the study was collected, a 5-item data collection tool prepared by the researcher. Working group was composed of a total of 207 teachers selected via "simple random sampling" from the universe. Results showed that teachers needed development in the following areas mostly: "extracurricular and classroom activities", "instructional programs and evaluation", "teacher-student relationships" and "organization of instructional environments". Teacher stated that they met their professional development needs in the following order from the most to least: through own individual studies, social learning among colleagues, in-service training, school administration and educational inspection.
\end{abstract}

\section{Keywords}

Teacher, Professional Development, Provision of Professional Development

\section{Introduction}

It is thought that pre-service training provided by teachers is not sufficient to effectively undertake the services 
they provide. Changes in education and school systems, globalization and transformation process, renewal of instructional programs, advances in educational technologies, different expectations of the environment and labor market from schools, impact of economic and political systems and increased discipline problems related to students are among the variables that necessitate teachers to develop and renew themselves. All these variables require that teachers should be provided with professional development opportunities.

Five systems that meet teachers' professional development needs can be cited: inspection units whose main job descriptions include providing guidance and on-the-job training activities to educational staff, school administrations that prioritize teachers' educational leadership roles, local and central in-service training programs, social learning among colleagues and teachers’ personal studies.

\subsection{Educational Inspection}

While traditional organization and management theories consider inspection as the process of controlling human behavior, modern organization and management theories define inspection as the guidance and on-the-job training activities to develop professional competences of staff. Inspection systems exist in all complex systems and they are organizational and administrative obligations (Aydın, 1993). Inspection is an indispensable process in social activities in which human element is especially dominant (Cengiz, 1998). Importance of inspection will be better comprehended when structure of organizations, management processes and systems theory are examined (Taymaz, 1997). Imperative nature of inspection is a natural result of the organization's determination to sustain itself (Aydın, 1993). Başaran (1996) who regards inspection as one of the sub processes of administration states that it is universal and no organization can work without inspection regardless of its type, purpose or establishment.

Inspection adapted to education and training is defined as educational inspection. "In this context, all inspection activities organized and implemented in educational institutions should be defined and named as educational inspection" (Başaran, Bozkurt, Karabıyık, 2003). Inspection is an element of administration process and therefore an element of the school management. It helps obtaining the degree of realization in pre-determined education and training goals (Bursalığlu, 1994). Rapidly changing requests about schools in order to increase productivity and quality in education have increased the importance given to inspection in recent years (Seçkin, 1991: p. 202).

Educational inspection is defined as the process that include all of the following: identifying the degree of realization in established organizational purposes, monitoring and correcting the operations of the organization, controlling staff behaviors and providing guidance and counseling services to teachers and other personnel (Aydın, 1993, Başaran, 1996, Bursalığlu,1994, Dağl1, 2003, Kaya, 1986, Taymaz, 1993). As a sub system of education, inspection aims to identify and improve the degree of implementation regarding educational goals (Gökçe, 2004). Goals of the organization are better comprehended through inspection, procedures are followed and necessary precautions are taken when goals are not met (Seçkin, 1991). Inspection has an essential function and value in all organizational systems in general and in education and school systems in particular (Aslan, 1999). The modern approaches to educational inspection consist of inspection approaches that center around guidance and on-the-job training and that aim to provide self-control skills. It is necessary to meet teachers' professional development needs at schools through inspection.

\subsection{School Administration}

Today, school administrators are expected to lead teachers and students. Many of the authors in the field of management define leadership as a process of guiding and affecting human efforts to reach specific aims (Hodgetts, 1999). In the most general sense, leadership is a social process that affects group members' interpretation of internal and external events, goal selection, activity organization, individual motivation and skills, power relationships and common aspects (Hoy and Miskel, 2010).

Various leadership styles have emerged due to advances in organizational and administrative sciences, emerging complexities in organizations and diversifications in societal expectations from organizations. Dominant leadership style in educational organizations is reflected as instructional leadership style. Instructional leadership consists of defining the school mission, managing the instructional program and teaching and developing a positive learning climate dimensions (Hallinger and Murphy, 1985). Instructional leadership was developed in line with school Administration and it is a leadership style that focuses on teaching (Çelik, 2003). In- 
structional leadership both focuses on classroom practices and concretizes the identified goals included in the school mission (Bennet and Anderson, 2003). Therefore it is crucial to for school administrators to undertake their job descriptions in a manner that will highlight their instructional leadership roles.

Gümüşeli (1996) emphasizes the most important characteristic that differentiates instructional leadership from other leadership styles as the focus on learning processes and its direct relation to teaching processes that include students, teachers and instructional program. Instructional leadership should increase performance in teaching, learning and guidance fields, it should be holistic and pragmatic and include value management and cultural activities (Aytaç, 2000). It is believed that the need for instructional leadership is growing at schools. School administrators are expected to contribute to teachers' professional developments through instructional leadership.

\subsection{In-Service Training}

While education can be classified in various ways, education in work life is generally examined under two headings: pre-service and in-service training. Personnel in sectors that produce goods or services are unable to catch up with the advances and knowledge accumulation due to the fast paced knowledge era, rapid changes in all fields and increased knowledge accumulation. Insufficient pre-service training is perceived as an important problem that needs to be overcome in order to successfully undertake tasks and obtain maximum productivity and efficiency. Educators and business managers that perceive the problem have needed various mechanisms to develop knowledge, skills and experiences of their staff and to provide them with the technological and administrative development in their sectors. One of these mechanisms is in-service training programs.

In-service training is defined as a type of training provided during service which includes systematic provision of required knowledge, skills and behaviors to prepare the personnel for further careers (Armutçuoğlu, 1992; Can, Akgün, \& Kavuncu, 1995; Eryılmaz, 1995; Gözübüyük, 1998; Taymaz, 1992). Tortop (1994) regards this process as the goals of in-service training.

Ersan (1992) examined in-service training in the context of educational organizations and stated that inservice training term is used to define planned activities implemented to develop the professional knowledge, skills, behaviors and performances of educational staff. Özyürek (1981) listed the reasons that require teacher training through in-service programs as advances in science, changes in society, developments at schools, changes in teachers themselves, changes in teaching processes, developments in the field of child development and the requirement to overcome deficiencies resulting from pre-service training and to fill in the gaps in communication. In-service training programs organized by the Ministry of Education aim to ensure teachers' professional development.

\subsection{Social Learning among Colleagues}

It is known that most learning takes place as a result of social learning via interactions and observations among individuals. Although it was Dewey who pointed to mutual learning concepts for the first time (Bayrakç1, 2007), social learning theory was presented by Bandura to explain learning styles of individuals. In simplest terms, social learning is defined as changes in behavior and knowledge based on observing others' behaviors in social groups (Ganis, 2009). One of the most important principles of social learning theory is individuals' capacity to think about themselves, make judgments and reflect those thoughts and judgments (Senemoğlu, 2004: p. 225). Social learning theory is explained in 4 ways: modeling, observation learning, identification and internalization (Bandura, 1971). Social learning process is composed of four steps: attention, retention, reproduction and motivation (Aydın, 2010, Ganis, 2009, Malone, 2002).

Teachers have the opportunity to interact with their colleagues in various committees and commissions and in social functions. Social learning is expected to emerge as a result of these interactions.

\subsection{Teachers' Personal Studies}

One of the ways individuals learn is through individual work. Individual learning is realized as a result of individual experiences (Ellison \& Fudenberg, 1993, Vriend 2000). Learning pace and capacity is different for each individual and everyone has unique learning and study styles. Therefore, same stimuli do not have the same effect on different individuals. Individual learning allows individuals to learn at their own pace and capacity. Individual learning activities give individuals the opportunity to be active in and guide their own learning. Teachers' 
personal studies are expected to play a role in meeting teachers’ professional development needs.

\section{Methodology}

The research model is a mixed model type. Findings related to identification of teachers' professional development needs were collected through quantitative methods whereas findings related to systems that meet those needs were collected qualitatively. The study utilized survey model since it identified teachers' professional development needs and investigated the systems that meet those needs. The part of the study related to identification of teachers' professional development needs was quantitative and the section that investigated the systems that meet professional development needs was qualitative. Data regarding the quantitative part of the study was collected with a data collection tool composed of 34 items prepared by the researcher and the data regarding the qualitative part of the study was collected a 5-item data collection tool prepared by the researcher.

\subsection{Participants}

The universe of the study was composed of teachers employed in Gaziantep Province in 2012-2013 academic years. Study sample conssited of a total of 207 teachers selected via "simple random sampling" from the universe.

Table 1 displays that $40.7 \%$ of the participants were female and $59.3 \%$ were male. $58.1 \%$ of the teachers worked in primary schools and $41.9 \%$ worked in secondary schools. Distribution of participating teachers according to seniority was as follows: 45.9\%: 1 - 5 years, 26.7\%: 6 - 10 years, 40\%: 11 - 15 years and 17.6\%: 16 years and higher. $87.4 \%$ of the participating teachers graduated from undergraduate programs and $12.6 \%$ graduated from post graduate programs. $87 \%$ were teachers whereas $13 \%$ were given the title of expert teachers.

\subsection{Scale Development Process}

Data collection tool with three sections developed by the researcher was used in the study to collect data. First section of the data collection tool includes personal information form to identify individual variables; second section is composed of a Likert-type scale to identify teachers' professional development needs and third section consists of a qualitative interview form regarding the systems used to meet teachers' on-the-job training needs.

6-step process proposed by Lester and Bishop (2000) was taken into consideration during the scale development process. Theoretical resources were reviewed in the first step and an item pool related to teacher development was created. In addition, 5 educational inspectors, 5 school administrators and 5 teachers were given semistructured interview forms to obtain their views on teachers' professional development needs and the systems used to meet those needs. The first item pool included 52 items and 5 qualitative questions. 5 school administrators, 5 academicians, 5 educational inspectors and 5 teachers were asked to review the items regarding teachers'

\begin{tabular}{llcc} 
Table 1. Demographic characteristics of teachers. & \\
\hline & Characteristic & $\mathrm{N}$ & $\%$ \\
\hline \multirow{2}{*}{ Gender } & Male & 110 & 40.7 \\
\multirow{2}{*}{ Institution } & Female & 160 & 59.3 \\
& Primary & 157 & 58.1 \\
& Secondary & 113 & 41.9 \\
Level of Education & Undergraduate & 236 & 87.4 \\
& Postgraduate & 34 & 12.6 \\
& 1 - 5 & 43 & 15.9 \\
Seniority & 6 - 10 & 72 & 26.7 \\
& $11-15$ & 108 & 40.0 \\
& $16-+$ & 47 & 17.6 \\
Title & Expert teacher & 235 & 87.0 \\
& Teacher & 35 & 13.0 \\
\hline
\end{tabular}


professional development needs. Based on the suggestions following the review, similar items were removed, statements were reviewed, number of items was reduced to 38 and the number of qualitative questions was kept the same (5). Items in the item pool were implemented on 85 teachers to test intelligibility. Teacher feedback was received through interviews about several features such as item intelligibility and period of implementation and suggestions were taken into consideration. Cronbach Alpha reliability coefficient of the scale in this step (piloting) was found to be .97 .

In order to test content validity based on expert views, the 38-item scale was reviewed again by 5 school administrators, 5 academicians and 5 educational inspectors. These individuals assessed the intelligibility of each item and stated their ideas about the ub groups these items belonged to. They also provided feedback regarding the items suggested for removal or addition. Based on the ideas of the field experts, 4 scale items were removed. Therefore, the scale form used to test reliability and validity included 34 items and 5 qualitative questions.

The draft data collection tool was implemented on 310 teachers employed in the province of Gaziantep and 270 of the returned 275 forms were analyzed. The data collection form composed of 34 items with 5-point Likert type options (None, Very Little, Partially, Mostly and Completely) and 5 qualitative questions was finalized. Teachers were also asked to write their reasons along with the degree of agreement while answering the qualitative questions.

\subsection{Reliability Analysis and Construct Validity}

Construct validity was examined in this study to undertake validity work for the scale. Exploratory factor analysis (EFA) and confirmatory factor analysis (CFA) was used to present construct validity of the scale. While CFA is used to assess the degree of overlap between the factors generated from various variables based on a foundation and the actual data, EFA is used to generate few identified meaningful constructs from various items (variables) that can be explained by these items together (Büyüköztürk, 2007). Later, sampling adequacy (KaiserMeyer-Olkin measure of sampling adequacy) and Barlett Sphericity analyses were undertaken and KMO measure of sampling adequacy coefficient was found to be .941 and Barlett Sphericity test K2 value was calculated to be 4922,481 (378) $(p=.000)$. In order for the data to be adequate for factor analysis, the KMO value should be higher than .60 and Barlett test should be significant (Büyüköztürk, 2007). The fact that KMO values obtained here were higher than .90 shows perfect data adequacy for factor analysis (Hutcheson \& Sofroniou, 1999). Factor load values of the data collection tool are presented in Table 2.

Factor analysis was undertaken on the scale to identify statistically related items. Rotation: Varimax, a factor analysis method, was used to determine the factor structure of the scale. Factor load values were observed to change between .39 and .80. Items with factor loads that were .39 or higher were collected in the same factor. Factor load values of .45 or higher is a good criterion for selection. However, this value can be decreased to .30 for few items (Büyüköztürk, 2007). Items 11, 12, 19, 21, 27 and 29 that had no load values under any factor were removed from the scale and the scale was finalized with 28 questions and 4 factors. Factor analysis results showed a scale with 4 factors that were named "extracurricular and classroom activities", "instructional programs and evaluation”, "teacher-student relationships” and “organization of instructional environments”. Cron-

Table 2. Factor load values of the data collection tool.

\begin{tabular}{|c|c|c|c|c|c|c|c|}
\hline Item & 1. Factor & Item & 2. Factor & Item & 3. Factor & Item & 4. Factor \\
\hline 16 & .522 & 1 & .723 & 3 & .589 & 31 & .729 \\
\hline 17 & .542 & 2 & .768 & 4 & .442 & 32 & .725 \\
\hline 18 & .566 & 5 & .564 & 6 & .531 & 33 & .744 \\
\hline 22 & .710 & 8 & .686 & 7 & .532 & 34 & .675 \\
\hline 23 & .696 & 9 & .634 & 10 & .464 & & \\
\hline 24 & .758 & 13 & .343 & 14 & .656 & & \\
\hline 25 & .679 & & & 15 & .534 & & \\
\hline 26 & .687 & & & 20 & .681 & & \\
\hline 28 & .584 & & & & & & \\
\hline 30 & .688 & & & & & & \\
\hline
\end{tabular}


bach Alpha reliability coefficient for each factor was calculated to be $.815 ; .831 ; .838$ and .886 respectively and the reliability coefficient for the whole scale was .88 .

\subsection{Reliability Analysis and Construct Validity}

The scale was declared valid since the facts that the scale explained the total variance with adequate percentage, had high factor loads in three factors and proved that it could evaluate what it set out to evaluate. In addition to EFA, CFA was also implemented on the scale. Factor loads of the model are provided in Figure 1.

Single-factor scale obtained through EFA was applied CFA in AMOS program. CFA showed that all items in the scale fit the 3-factor structure and the obtained goodness-of-fit indices presented good values. Table 3 presents the fit of CFA results.

CMIN/df ratio smaller than $<5.0$ (Kline, 2005), GFI value larger than $>.90$ (Miles \& Shevlin, 1998), RMSEA

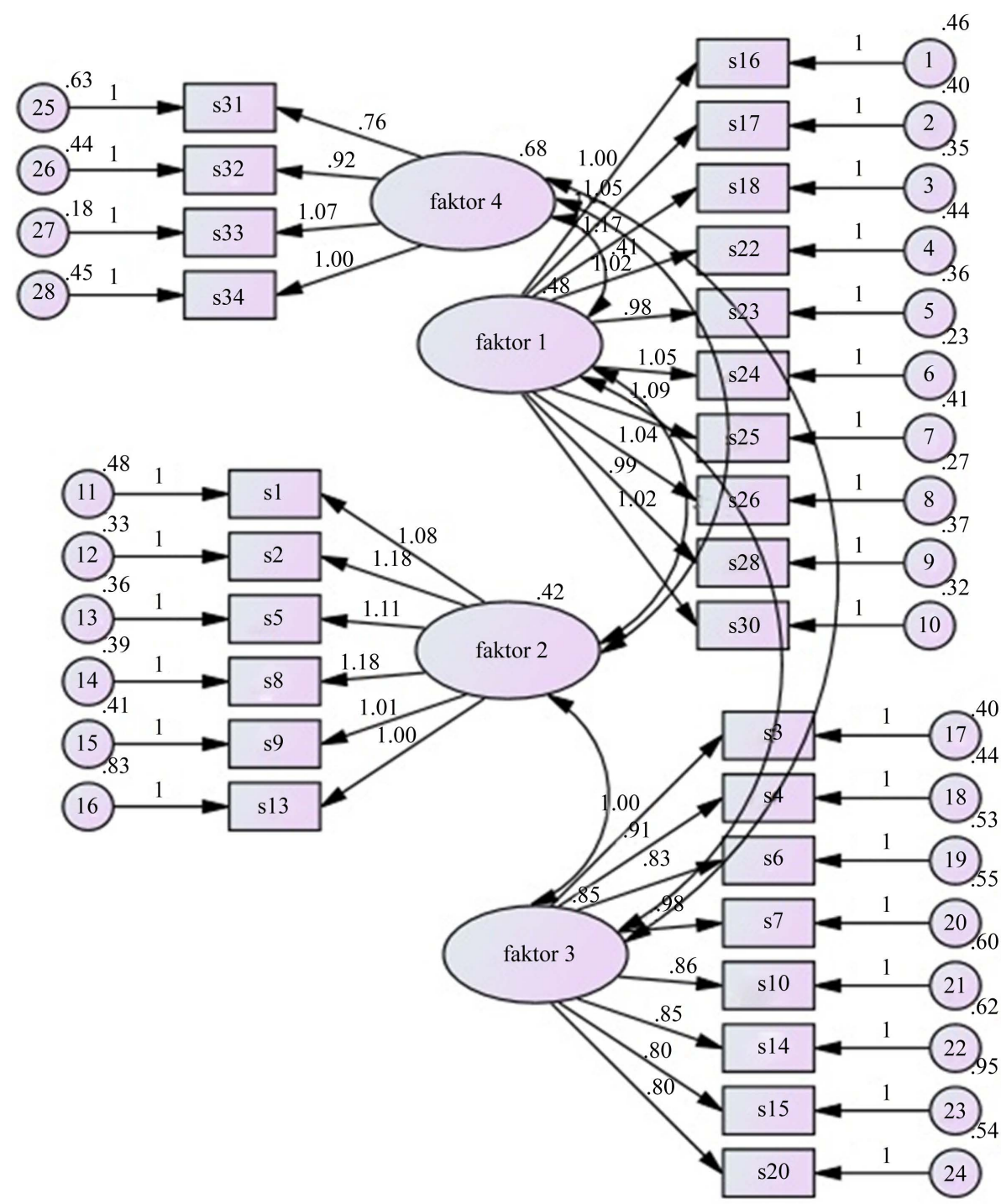

Figure 1. CFA diagram.

Table 3. Goodness-of-fit indices values.

\begin{tabular}{ccccccc}
\hline CMIN $\left(\chi^{2}\right)$ & df & $p$ & RMR & GFI & RMSEA & CMIN/df \\
\hline 953,224 & 344 & .000 & .05 & .81 & .081 & 2.771 \\
\hline
\end{tabular}


value lower than <.08 (Steiger, 2007), RMR value of $\leq .05$ (Tabachnik \& Fidell, 2007), GFI value larger than >.80 are regarded base values for goodness-of-fit between model and data (Anderson \& Gerbing, 1984; Marsh, Balla \& McDonald, 1988). Examination of Table 3 based on these base values, onbtained results are $\mathrm{RMR}=.05 \leq .05 ; \mathrm{GFI}=.81>.80 ; \mathrm{RMSEA}=.08 \leq .08$ and CMIN/df $=2.771<3.0$. Values of goodness-of-fit between model and data show good fit and that construct validity obtained with EFA was validated through CFA. Therefore, the scale is thought to have construct validity.

\subsection{Reliability Analysis and Construct Validity}

Views provided to the question related to “teachers' professional development needs" were calculated in terms of arithmetic means and standard deviation. Independent samples t-test was undertaken to determine whether there were significant differences between the variables of teachers' gender and title and their views and ANOVA analysis methods were implemented to determine whether there were significant differences in teacher views based on seniority and school type. $p=.05$ level of significance was adopted in the study. A Likert type scale scored 1 - 5 (None-1; Very Little-2; Partially-3; Mostly-4 and Completely-5) was used in interpreting teacher views regarding “teachers' professional development needs". "Width of Interval = Range/Number of Groups” formula was used to evaluate arithmetic means and score intervals were determined as $4 / 5=.80$. Descriptive analysis methods were used in analyzing the qualitative data regarding the systems teachers used to meet their professional development needs. Answers provided to each question in the semi-structured interview form were examined separately and in detail, answers that had similar or common aspects were selected and coded. Following the coding, similar answers provided for the same question or answers with common themes were collected under specific categories and teacher views were presented based on the codes.

\section{Findings}

Table 4 presents the arithmetic means and standard deviations based on teacher views regarding professional development needs

According to Table 4, based on the factors included in the data collection tool, teachers expressed that they needed "very little" on-the-job training regarding "extracurricular and classroom activities" dimension (mean: 1.97), "very little” on-the-job training regarding "instructional programs and evaluation" dimension (mean: 2.29); "partial” on-the-job training regarding "organization of instructional environments" (mean: 2.61) and "very little” on-the-job training regarding “teacher -student relationships” dimension (mean: 2.57). Teachers expressed that they needed "very little" on-the-job training regarding all dimensions included in the data collection tool (mean: 2.36). Accordingly, teachers need the least on-the-job training in "extracurricular and classroom activities" and the most on-the-job training in "organization of instructional environments".

The study examined whether there were significant differences between “teachers' on-the-job training needs” and their gender and the results are provided in Table 5.

Table 5 shows no significant relationships between teacher views regarding "extracurricular and classroom activities” and “teacher-student relationships” dimensions based on gender. However, significant relationships were identified between teacher views regarding “instructional programs and evaluation” and "organization of instructional environments" depending on gender. Compared to female teachers, male teachers were found to express more need for on-the-job training in "instructional programs and evaluation” and "organization of instructional environments” dimensions.

The research investigated whether there were significant differences between "teachers' on-the-job training needs” and their titles and the results are provided in Table 6.

Table 6 shows no significant relationships between teacher views regarding "teacher-student relationships" and "instructional programs and evaluation" dimensions based on title. However, significant relationships were identified between teacher views regarding "extracurricular and classroom activities” and "organization of instructional environments" depending on title. Compared to expert teachers, teachers were found to express more need for on-the-job training in "extracurricular and classroom activities" and "organization of instructional environments" dimensions.

The study examined the data to specify whether there were significant differences between “teachers' on-thejob training needs" and their seniority and the results are provided in Table 7.

Table 7 shows no significant relationships between teacher views regarding “teacher-student relationships”, 
Table 4. Teachers’ on-the-job training needs.

\begin{tabular}{cccc}
\hline Factor & N & M & SD \\
\hline 1. Extracurricular and classroom activities & 270 & 1.9774 & .74772 \\
2. Instructional programs and evaluation & 270 & 2.2963 & .76563 \\
3. Organization of instructional environments & 270 & 2.6185 & .70014 \\
4. Teacher-student relationships & 270 & 2.5787 & .84074 \\
\hline
\end{tabular}

Table 5. Independent t-test results based on gender variable.

\begin{tabular}{|c|c|c|c|c|c|c|c|c|c|}
\hline \multirow{2}{*}{ Factor } & \multirow{2}{*}{ Gender } & \multirow{2}{*}{$\mathrm{N}$} & \multirow{2}{*}{ M } & \multirow{2}{*}{ SD } & \multicolumn{2}{|c|}{ Levene Test } & \multirow{2}{*}{ df } & \multirow{2}{*}{$\mathrm{t}$} & \multirow{2}{*}{$p$} \\
\hline & & & & & $\mathrm{F}$ & $p$ & & & \\
\hline \multirow{2}{*}{ 1. Extracurricular and classroom activities } & Female & 110 & 1.9382 & .77944 & \multirow{2}{*}{1.676} & \multirow{2}{*}{.197} & \multirow{2}{*}{268} & \multirow{2}{*}{.714} & \multirow{2}{*}{.476} \\
\hline & Male & 160 & 2.0044 & .72635 & & & & & \\
\hline \multirow{2}{*}{ 2. Instructional programs and evaluation } & Female & 110 & 2.0924 & .69312 & \multirow{2}{*}{1.369} & \multirow{2}{*}{.243} & \multirow{2}{*}{268} & \multirow{2}{*}{3.713} & \multirow{2}{*}{.000} \\
\hline & Male & 160 & 2.4365 & .78349 & & & & & \\
\hline \multirow{2}{*}{ 3. Organization of instructional environments } & Female & 110 & 2.4614 & .68019 & \multirow{2}{*}{.117} & \multirow{2}{*}{.732} & \multirow{2}{*}{268} & \multirow{2}{*}{3.107} & \multirow{2}{*}{.002} \\
\hline & Male & 160 & 2.7266 & .69522 & & & & & \\
\hline \multirow{2}{*}{ 4. Teacher-student relationships } & Female & 110 & 2.5386 & .82547 & \multirow{2}{*}{.382} & \multirow{2}{*}{.537} & \multirow{2}{*}{268} & \multirow{2}{*}{.649} & \multirow{2}{*}{.517} \\
\hline & Male & 160 & 2.6063 & .85255 & & & & & \\
\hline
\end{tabular}

Table 6. Independent t-test results based on gender variable.

\begin{tabular}{|c|c|c|c|c|c|c|c|c|c|}
\hline \multirow{2}{*}{ Factor } & \multirow{2}{*}{ Title } & \multirow{2}{*}{$\mathrm{N}$} & \multirow{2}{*}{ M } & \multirow{2}{*}{ SD } & \multicolumn{2}{|c|}{ Levene Test } & \multirow{2}{*}{$\mathrm{df}$} & \multirow{2}{*}{$\mathrm{t}$} & \multirow{2}{*}{$p$} \\
\hline & & & & & $\mathrm{F}$ & $p$ & & & \\
\hline \multirow{2}{*}{$\begin{array}{l}\text { 1. Extracurricular and } \\
\text { classroom activities }\end{array}$} & Teachers & 235 & 2.0204 & .75533 & \multirow{2}{*}{2.570} & \multirow{2}{*}{.110} & \multirow{2}{*}{268} & \multirow{2}{*}{2.473} & \multirow{2}{*}{.014} \\
\hline & Expert Teachers & 35 & 1.6886 & .63095 & & & & & \\
\hline \multirow{2}{*}{$\begin{array}{l}\text { 2. Instructional programs } \\
\text { and evaluation }\end{array}$} & Teachers & 235 & 2.3014 & .76998 & \multirow{2}{*}{.298} & \multirow{2}{*}{.586} & \multirow{2}{*}{268} & \multirow{2}{*}{.284} & \multirow{2}{*}{.776} \\
\hline & Expert Teachers & 35 & 2.2619 & .74567 & & & & & \\
\hline \multirow{2}{*}{$\begin{array}{l}\text { 3. Organization of } \\
\text { instructional environments }\end{array}$} & Teachers & 235 & 2.6548 & .70278 & \multirow{2}{*}{1.327} & \multirow{2}{*}{.250} & \multirow{2}{*}{268} & \multirow{2}{*}{2.222} & \multirow{2}{*}{.027} \\
\hline & Expert Teachers & 35 & 2.3750 & .63954 & & & & & \\
\hline \multirow{2}{*}{$\begin{array}{l}\text { 4. Teachers-student } \\
\text { relationships }\end{array}$} & Teachers & 235 & 2.5968 & .82751 & \multirow{2}{*}{.765} & \multirow{2}{*}{.383} & \multirow{2}{*}{268} & \multirow{2}{*}{.917} & \multirow{2}{*}{.360} \\
\hline & Expert Teachers & 35 & 2.4571 & .92848 & & & & & \\
\hline
\end{tabular}

“instructional programs and evaluation”, “extracurricular and classroom activities” and “organization of instructional environments” dimensions.

The research investigated whether there were significant differences between “teachers' on-the-job training needs” and place of employment and the results are provided in Table 8.

Table 8 shows no significant relationships between teacher views regarding "teacher-student relationships" and "instructional programs and evaluation" dimensions based on place of employment. However, significant relationships were identified between teacher views regarding "extracurricular and classroom activities” and "organization of instructional environments" depending on place of employment. Compared to primary school teachers, secondary school teachers were found to express more need for on-the-job training in "extracurricular and classroom activities” and “organization of instructional environments” dimensions.

Based on data obtained from the study, teacher views regarding the contribution of inspection units on teachers' professional development are provided in Table 9.

123 teachers commented on the item "Inspection units contribute to my professional development” and 72 stated that they disagreed, 37 partially agreed and 14 completely agreed. Based on this finding, it can be suggested that inspection units do not provide contribution to teachers' professional development at the required level. 
Table 7. One way ANOVA results based on seniority variable.

\begin{tabular}{|c|c|c|c|c|c|c|c|}
\hline Factor & Seniority & $\mathrm{N}$ & M & SD & df & $\mathrm{F}$ & $p$ \\
\hline \multirow{5}{*}{$\begin{array}{l}\text { Extracurricular and classroom } \\
\text { activities }\end{array}$} & $1-5$ & 43 & 2.0605 & .77587 & & \multirow{5}{*}{.317} & \multirow{5}{*}{.813} \\
\hline & $6-10$ & 72 & 1.9722 & .72602 & 3 & & \\
\hline & $11-15$ & 108 & 1.9787 & .73739 & & & \\
\hline & $16-+$ & 47 & 1.9064 & .79356 & \multirow{2}{*}{266} & & \\
\hline & Total & 270 & 1.9774 & .74772 & & & \\
\hline \multirow{5}{*}{$\begin{array}{l}\text { Instructional programs and eval- } \\
\text { uation }\end{array}$} & $1-5$ & 43 & 2.1202 & .76750 & & \multirow{5}{*}{1.057} & \multirow{5}{*}{.368} \\
\hline & $6-10$ & 72 & 2.3148 & .72057 & 3 & & \\
\hline & $11-15$ & 108 & 2.3102 & .80801 & & & \\
\hline & $16-+$ & 47 & 2.3972 & .72777 & \multirow{2}{*}{266} & & \\
\hline & Total & 270 & 2.2963 & .76563 & & & \\
\hline \multirow{5}{*}{$\begin{array}{l}\text { Organization of instructional } \\
\text { environments }\end{array}$} & $1-5$ & 43 & 2.5901 & .69561 & & \multirow{5}{*}{.888} & \multirow{5}{*}{.448} \\
\hline & $6-10$ & 72 & 2.7326 & .68346 & 3 & & \\
\hline & $11-15$ & 108 & 2.5660 & .72131 & & & \\
\hline & $16-+$ & 47 & 2.5904 & .68202 & \multirow{2}{*}{266} & & \\
\hline & Total & 270 & 2.6185 & .70014 & & & \\
\hline \multirow{5}{*}{ Teacher-student relationships } & $1-5$ & 43 & 2.6337 & .96724 & & \multirow{5}{*}{.331} & \multirow{5}{*}{.803} \\
\hline & $6-10$ & 72 & 2.6285 & .77708 & 3 & & \\
\hline & $11-15$ & 108 & 2.5185 & .79551 & & & \\
\hline & $16-+$ & 47 & 2.5904 & .92728 & \multirow{2}{*}{266} & & \\
\hline & Total & 270 & 2.5787 & .84074 & & & \\
\hline
\end{tabular}

Table 8. Independent t-test results based on place of eployment variable.

\begin{tabular}{|c|c|c|c|c|c|c|c|c|c|}
\hline \multirow{2}{*}{ Factor } & \multirow{2}{*}{$\begin{array}{c}\text { Place of } \\
\text { Employment }\end{array}$} & \multirow{2}{*}{$\mathrm{N}$} & \multirow{2}{*}{$\mathrm{M}$} & \multirow{2}{*}{ SD } & \multicolumn{2}{|c|}{ Levene Test } & \multirow{2}{*}{ df } & \multirow{2}{*}{$\mathrm{t}$} & \multirow{2}{*}{$p$} \\
\hline & & & & & $\mathrm{F}$ & $p$ & & & \\
\hline \multirow{2}{*}{$\begin{array}{l}\text { 1. Extracurricular and } \\
\text { classroom activities }\end{array}$} & Primary & 157 & 1.8968 & & \multirow{2}{*}{1.141} & \multirow{2}{*}{.286} & \multirow{2}{*}{268} & \multirow{2}{*}{2.10} & \multirow{2}{*}{.037} \\
\hline & Secondary & 113 & 2.0894 & .76874 & & & & & \\
\hline \multirow{2}{*}{$\begin{array}{l}\text { 2. Instructional programs } \\
\text { and evaluation }\end{array}$} & Primary & 157 & 2.2803 & .81955 & \multirow{2}{*}{4.510} & \multirow{2}{*}{.035} & \multirow{2}{*}{268} & \multirow{2}{*}{.405} & \multirow{2}{*}{.686} \\
\hline & Secondary & 113 & 2.3186 & .68666 & & & & & \\
\hline \multirow{2}{*}{$\begin{array}{l}\text { 3. Organization of } \\
\text { instructional environments }\end{array}$} & Primary & 157 & 2.4809 & .74828 & \multirow{2}{*}{5.780} & \multirow{2}{*}{.017} & \multirow{2}{*}{268} & \multirow{2}{*}{3.907} & \multirow{2}{*}{.000} \\
\hline & Secondary & 113 & 2.8097 & .57794 & & & & & \\
\hline \multirow{2}{*}{$\begin{array}{l}\text { 4. Teacher-student } \\
\text { relationships }\end{array}$} & Primary & 157 & 2.5573 & .89955 & \multirow{2}{*}{3.120} & \multirow{2}{*}{.078} & \multirow{2}{*}{268} & \multirow{2}{*}{.492} & \multirow{2}{*}{.623} \\
\hline & Secondary & 113 & 2.6084 & .75436 & & & & & \\
\hline
\end{tabular}

Teachers who stated that inspection units did not contribute to their professional development expressed that inspectors did not allocate sufficient time for teachers, tended to focus on finding mistake sand faults and had low levels of professional competence. Teachers who thought inspectors partially contributed to their professional developments mentioned that inspectors did not provide inspection at sufficient levels, had differences in practice and contributed to professional development mostly through guidance. However, teachers who stated that inspectors completely contributed to their professional development expressed that inspectors were experts in guidance, provided constructive suggestions and had high levels of professional experience.

Teacher views regarding the contributions of local and central in-service training activities on their professional developments are provided in Table 10.

127 teachers commented on the item "in-service training activities contribute to my professional development" and 38 stated that they disagreed, 41 partially agreed and 48 completely agreed. Based on this finding, it can be suggested that in-service training activities moderately contribute to teachers' professional development. 
Table 9. Teacher views on inspection units’ contribution to their professional development.

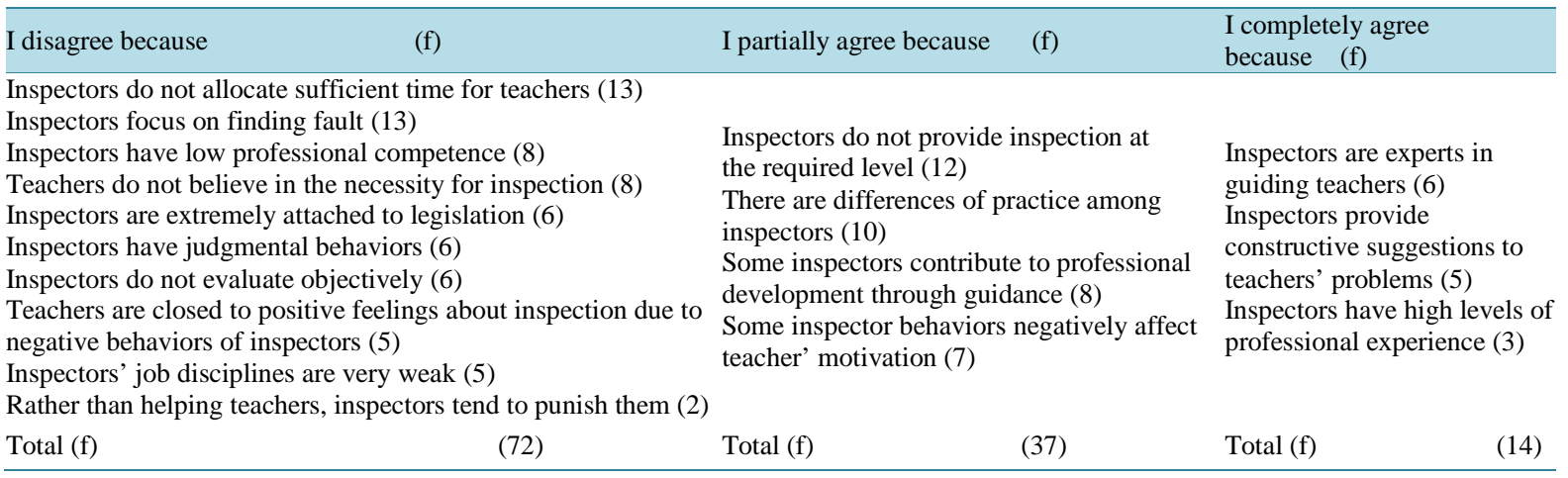

Table 10. Teacher views regarding the contributions of local and central in-service training activities on their professional developments.

\begin{tabular}{|c|c|c|}
\hline I disagree because & partially agree because & I completely agree because \\
\hline $\begin{array}{l}\text { Individuals who teach in in-service trainings } \\
\text { have low levels of competence (9) } \\
\text { In-service trainings are not provided in line } \\
\text { with their purpose (8) } \\
\text { Quality of in-service trainings are low (8) } \\
\text { Number of in-service trainings provided to } \\
\text { teachers is insufficient (6) } \\
\text { Selection of topics in in-service trainings are } \\
\text { ill-advised (5) } \\
\text { Participation in in-service trainings is not } \\
\text { voluntary (2) }\end{array}$ & $\begin{array}{l}\text { In-service trainings are not productive } \\
\text { enough (10) } \\
\text { In-service trainings allow us to follow } \\
\text { advances albeit a little (10) } \\
\text { In-service trainings are theoretical and } \\
\text { are not geared towards practice (8) } \\
\text { Content of in-service trainings are not } \\
\text { at desired level (7) } \\
\text { Motivation levels of teachers are low } \\
\text { regarding in-service trainings (6) }\end{array}$ & $\begin{array}{l}\text { In-service trainings allow us learn new topics (14) } \\
\text { In-service trainings develop teachers' existing } \\
\text { knowledge (9) } \\
\text { well-equipped in-service training environments result } \\
\text { in new learning (8) } \\
\text { In-service trainings include contemporary topics (8) } \\
\text { Interesting methods are used in in-service trainings } \\
\text { (5) } \\
\text { Interaction is strong in in-service trainings (4) } \\
\text { Individuals who teach in in-service trainings are } \\
\text { experts in their fields (3) }\end{array}$ \\
\hline Total (f) & Total (f) & Total (f) \\
\hline
\end{tabular}

Teachers who stated that in-service training activities did not contribute to their professional development expressed that individuals who teach in in-service trainings had low levels of competence, in-service trainings were not provided in line with their purpose and their quality was low. Teachers who thought in-service training activities partially contributed to their professional developments mentioned that in-service trainings were not productive enough, did not fully provide information about changes and innovations and they were not geared towards practice. However, teachers who stated that in-service training activities completely contributed to their professional development expressed that they learned about new topics in in-service training activities, developed their existing information and in-service training activities contributed to their developments since they were given in well-equipped environments.

Teacher views regarding the contributions of school administrators on their professional developments are provided in Table 11.

112 teachers commented on the item "school administrators contribute to my professional development" and 47 stated that they disagreed, 27 partially agreed and 28 completely agreed. Based on this finding, it can be suggested that school administrators do not provide contribution to teachers' professional development at the required level.

Teachers who stated that school administrators did not contribute to their professional development expressed that school administrators were professionally incompetent and had high workloads and teachers were unwilling to ask professional help from the school administrators. Teachers who thought school administrators partially contributed to their professional developments mentioned that it was easy to reach school administrators; they were well-intentioned towards teachers' on-the-job development and they taught different subject matters. However, teachers who stated that school administrators completely contributed to their professional development expressed that school administrators had more experience than teachers, knew the legislation very well and regarded teachers' achievement as their own achievement.

Based on data obtained from the study, teacher views regarding the contribution of social learning among colleagues on teachers' professional development are provided in Table 12. 
Table 11. Teacher views regarding the contributions of school administrators on their professional developments.

\begin{tabular}{|c|c|c|}
\hline I disagree because & I partially agree because & I completely agree because \\
\hline $\begin{array}{l}\text { School administrators are incompetent professionally } \\
\text { (14) } \\
\text { School administrators do not allocate time to support } \\
\text { teachers' on-the-job training due to their high } \\
\text { workloads (10) } \\
\text { Teachers are unwilling to ask professional help from } \\
\text { the school administrators (7) } \\
\text { School administrators' communication with teachers is } \\
\text { weak (8) } \\
\text { School administrators believe that teachers cannot } \\
\text { develop professionally (5) } \\
\text { School administrators are closed to change (3) }\end{array}$ & $\begin{array}{l}\text { It is easy to reach school administrators } \\
\text { (15) } \\
\text { School administrators are } \\
\text { well-intentioned towards teachers' } \\
\text { on-the-job development (8) } \\
\text { The fact that school administrators teach } \\
\text { different subject matters facilitates their } \\
\text { professional assistance to teachers (4) }\end{array}$ & $\begin{array}{l}\text { School administrators have more } \\
\text { experience than teachers (12) } \\
\text { School administrators know the legislation } \\
\text { very well (4) } \\
\text { School administrators feel responsible } \\
\text { from teachers' on-the-job training (5) } \\
\text { h School administrators regard teachers' } \\
\text { achievement as their own achievement (5) } \\
\text { School administrators want to support } \\
\text { teachers (2) }\end{array}$ \\
\hline Total (f) & Total (f) & Total (f) \\
\hline
\end{tabular}

Table 12. Teacher views regarding the contribution of social learning among colleagues on teachers’ professional development.

\begin{tabular}{|c|c|c|}
\hline I disagree because & I partially agree because & I completely agree because \\
\hline $\begin{array}{l}\text { Teachers are experiencing professional burn-out } \\
\text { (8) } \\
\text { Teachers talk about daily events rather than } \\
\text { professional topics (7) } \\
\text { Teachers are jealous of each other's success (5) } \\
\text { There are meaningless conflicts among teachers } \\
\text { (5) } \\
\text { Communication among teachers is weak (3) }\end{array}$ & $\begin{array}{l}\text { Sharing the same environment results } \\
\text { in interaction among teachers (11) } \\
\text { Sharing knowledge among teachers is } \\
\text { not always the case (8) } \\
\text { There are a few successful teachers at } \\
\text { the school (5) } \\
\text { There is competition among teachers } \\
\text { (4) }\end{array}$ & $\begin{array}{l}\text { There is a high level of knowledge sharing among } \\
\text { teachers (15) } \\
\text { Teachers cooperate for student success (13) } \\
\text { Teachers' communication with each other is easy } \\
\text { (12) } \\
\text { The fact that teachers have different ideas } \\
\text { contribute to professional development (11) } \\
\text { There is professional cooperation among teachers } \\
\text { (9) }\end{array}$ \\
\hline Total (f) & Total (f) & Total (f) \\
\hline
\end{tabular}

116 teachers commented on the item "social learning among colleagues contributes to my professional development" and 28 stated that they disagreed, 28 partially agreed and 60 completely agreed. Based on this finding, it can be suggested that social learning among colleagues contributes to teachers' professional development at high levels.

Teachers who stated that social learning among colleagues contributes did not contribute to their professional development expressed that teachers were experiencing professional burn-out, they talked about daily events rather than professional topics and they were jealous of each other's success. Teachers who thought social learning among colleagues partially contributed to their professional developments mentioned that sharing the same environment resulted in interaction among teachers, teachers did not always share information among themselves and there were only a few successful teachers at the school. However, teachers who stated that social learning among colleagues completely contributed to their professional development expressed that there was a high level of knowledge sharing among teachers, teachers cooperated for student success and they had different ideas.

Based on data obtained from the study, teacher views regarding the contribution of individual/personal studies on teachers' professional development are provided in Table 13.

109 teachers commented on the item "individual/personal studies contribute to my professional development" and 17 stated that they disagreed, 24 partially agreed and 68 completely agreed. Based on this finding, it can be suggested that individual/personal studies contribute to teachers' professional development at high levels.

Teachers who stated that individual/personal studies did not contribute to their professional development expressed that they were experiencing professional burn-out, they lacked the resources to develop themselves and they did not know how to benefit from resources. Teachers who thought individual/personal studies partially contributed to their professional developments mentioned that they could not allocate sufficient time for individual studies due to their busy daily lives, teachers who developed themselves were not appreciated and low teacher salaries negatively created loss of motivation for personal studies. However, teachers who stated that individual/personal studies completely contributed to their professional development expressed that individual studies allowed opportunities for independent work, it was easy to be motivated for individual studies and desire for promotion led to individual studies. 
Table 13. Teacher views regarding the contribution of individual/personal studies on teachers’ professional development.

\begin{tabular}{|c|c|c|}
\hline ause & I partially agree because & I completely agree because \\
\hline $\begin{array}{l}\text { Teachers are experiencing professional } \\
\text { burn-out (8) } \\
\text { Teachers lack resources to develop } \\
\text { themselves (5) } \\
\text { Teachers do not know how to benefit from } \\
\text { resources (4) } \\
\text { Teachers have problems obtaining } \\
\text { resources to develop themselves due to } \\
\text { economic problems (2) }\end{array}$ & $\begin{array}{l}\text { Teachers cannot allocate sufficient time } \\
\text { for individual studies due to their busy } \\
\text { daily lives (14) } \\
\text { The fact that teachers who develop } \\
\text { themselves are not appreciated decreases } \\
\text { motivation (6) } \\
\text { Low teacher salaries negatively affect } \\
\text { individual/personal development (4) }\end{array}$ & $\begin{array}{l}\text { Individual studies allow opportunities for independent } \\
\text { work (16) } \\
\text { It is easy to be motivated for individual studies (15) } \\
\text { Desire for promotion leads to individual studies (8) } \\
\text { Desire to be a good teacher (7) } \\
\text { Knowing about their deficits makes individual studies } \\
\text { more effective for teachers (7) } \\
\text { More permanent learning is possible through individual } \\
\text { studies (7) } \\
\text { Individual studies are easier (6) } \\
\text { Teachers' love of their profession encourage individual } \\
\text { studies (2) }\end{array}$ \\
\hline otal (f) & Total (f) & Total (f) \\
\hline
\end{tabular}

Before you begin to format your paper, first write and save the content as a separate text file. Keep your text and graphic files separate until after the text has been formatted and styled. Do not use hard tabs, and limit use of hard returns to only one return at the end of a paragraph. Do not add any kind of pagination anywhere in the paper. Do not number text heads- the template will do that for you.

Finally, complete content and organizational editing before formatting. Please take note of the following items when proofreading spelling and grammar:

\section{Discussion}

In terms of the dimensions included in the data collection tool, teachers listed their professional development needs as extracurricular and classroom activities", "instructional programs and evaluation" "teachers-student relationships" and "organization of instructional environments" respectively. The fact that teachers need the highest amount of support in educational activities and in instructional programs and evaluation may be related to the fact that these fields have undergone tremendous changes recently.

Based on title variable, there were no significant differences in teacher views regarding their professional development needs in "teacher-student relationships" and "instructional programs and evaluation" dimensions. However, significant differences were observed in teacher views regarding their professional development needs in "extracurricular and classroom activities" and "organization of instructional environments" dimensions based on title. Teachers needed higher levels of on-the-job training in "extracurricular and classroom activities" and "organization of instructional environments" dimensions compared to expert teachers. This finding may be related to the fact that higher levels of competences are required to become expert teachers in career steps practice in Turkey.

Based on seniority, no significant differences were observed in teacher views regarding their professional development needs in "extracurricular and classroom activities", "teachers-student relationships", "instructional programs and evaluation" and "organization of instructional environments" dimensions included in the data collection tool.

Based on place of employment variable, there were no significant differences in teacher views regarding their professional development needs in "teacher-student relationships" and "instructional programs and evaluation" dimensions. However, significant differences were observed in teacher views regarding their professional development needs in "extracurricular and classroom activities" and "organization of instructional environments" dimensions based on place of employment. Compared to primary school teachers, secondary school teachers needed more on-the-job training in "extracurricular and classroom activities" and "organization of instructional environments" dimensions. This finding may be explained by the fact that compared to secondary school teachers, primary school teacher receive more training in vocational topics related to teaching during their pre-service education.

According to qualitative findings of the study, teacher listed how they met their professional development needs from the most to the least as follows: individual/personal studies, social learning among colleagues, inservice training, school administrator and the members of the educational inspection unit. According to this finding, teachers developed themselves the most through personal studies and through social learning and they 
benefited the least from educational inspectors and school administrators.

According to research findings, teachers receive the least amount of support from the members of the educational inspection unit. The fact that educational inspectors do not provide the desired impact on teachers' professional development has been presented in many studies (Sağır, 2005, Yüksel, 2001, Memsişoğlu, 2001, Gül, 2001, Kilıç, 1999, Büyükaslan, 1998, Ecevit, 1996, Bozkurt, 1995, Patterson, 1990, Hobson, 1990, Richardson, 1998, Sar1, 1987, Chunn, 1986).

The study also pointed to the fact that school administrators provide the desired impact on teachers' professional development. This finding is parallel to findings of other studies (Aslan, 2009, Derbedek, 2008, Gürsun, 2007, Aksoy, 2007, Süzeroğlu, 2006, Aksoy, 2006, İnceler, 2005, Polat, 1997, Gümüşeli, 1996). In their study, Sağır and Memişoğlu (2013 \& 2012) found that school administrators could not effectively play their instructional leadership roles and faced many problems in their leadership roles. Serin \& Buluç (2012) determined that school administrators' instructional leadership skills moderately contributed to teachers' organizational commitment.

Based on the findings of the study, it can be claimed that teachers moderately satisfy their professional development needs via in-service training activities. Bayrakçı (2009) compared in-service training activities provided to Turkish and Japanese teachers and found that Turkish teachers have problems regarding in-service training because the individuals who plan and implement those trainings are not experts. However these trainings are rather successful in Japan due to better technological infrastructure. Özer (2004) stated that although inservice training activities date back to 1960's in Turkey, they are not productive and there are still many problems to solve regarding these activities.

The study concluded that social learning contributed to teachers’ professional development. Bayrakç1's (2007) study also found that social learning plays an important role in individuals' learning and Solomonidou \& Kolokotronis (2008) and Pilatou \& Stavridou (2008) states that knowledge is created in social environments and social environments are effective in science education.

\section{Conclusion}

With each passing day, teachers feel the need for continuous professional development due to increased knowledge accumulation as a result of changes and transformation. Effective implementation of educational services depends on meeting these needs. It is found that teachers have professional development needs in the areas of "extracurricular and classroom activities", "instructional programs and evaluation" "teachers-student relationships" and "organization of instructional environments” respectively. It is observed that teachers satisfy these professional development needs respectively through individual studies, social learning among colleagues, in-service training, school administrators and educational inspection systems. It can be suggested that education, selection and assignment of administrators and educational inspectors should be reviewed in order to create more effective inspection units and school administrations that will satisfy teachers' professional development needs. Also, planning and implementation of in-service training activities geared towards teacher development can be undertaken more professionally.

\section{References}

Aksoy, E. (2006). Instructional Leadership Roles of Primary School Administrators. Master Thesis, Çanakkale: Çanakkale Onsekiz Mart University.

Armutçuoğlu, G. (1992). Required Qualities in Teachers Assigned to Teach in In-Service Training Activities. Journal of Education, 1, 86-117.

Aslan, M. (2009). Teacher Views Regarding Primary School Administrators' Instructional Leadership Roles in Implementing the New Primary School Curriculum. Master Thesis, Ankara: Gazi University.

Aslan, B. (1999). Inspection and Evaluation. In E. Toprakçı, Ed., Administation Candidates Training Program. Malatya: İnönü University Publications.

Aydın, A. (2010). Educational Psychology. Ankara: Pegem Academy.

Aydın, M. (1993). Modern Educational Inspection. Ankara: Pegem Publications.

Aytaç, T. (2000). School-Centered Management. Ankara: Nobel Publication and Distribution

Bandura, A. (1971). Psychological Modelling: Conflicting Theories. Chicago: Aldine-Atherton Inc. 
Başaran, I. E. (1996). Educational Administration. Ankara: Yargıcı Printing Press.

Bayrakçı, M. (2007). Social Learning Theory and Its Educational Applications. Journal of Sakarya University Education Fakulty, 198-2010.

Bayrakçı, M. (2009). In-Service Training in Japan and Turkey: A Comparative Analysis of Institutions and Practices. Australian Journal of Teacher Education, 34, 9-22.

Bennet, N., \& Anderson, L. (2003). Challenging the Conventions. In N. Bennet, \& L. Anderson (Eds.), Rethinking Educational Leadership (pp. 1). London: SAGE Publication Ltd.

Bozkurt, E. (1995). Assessment of Lesson Inspection in Primary Schools. Unpublished Master Thesis, Ankara: Ankara University Institute of Social Sciences.

Bursalığlu, Z. (1994). New Structures and Behaviors in School Administration. Ankara: Pegem Publications.

Büyükaslan, M. A. (1998). Primary School Teachers’ Perceptions and Expectations Regarding Primary School Inspectors’ Lesson Inspections. Unpublished Master Thesis, Kocaeli: Kocaeli University Institute of Social Sciences.

Büyüköztürk, S. (2007). Data Analysis Book for Social Sciences. Ankara: Pegem Publication.

Can, H., Akgün, A., \& Kavuncu, Ş. (1995). Personnel Management. Ankara: Siyasal Bookstore.

Cengiz, C. (1998). Ministry of Education, Education of Ministry Inspectors. Ankara: Pegem Publications.

Chunn, G. F. (1986). Perceptions of Teachers and Principals Concerning Behaviors and Attitudes that Contribute to an Effective Supervisory Cycle. Dissertation Abstracts International, 1861, 46(09).

Dağlı, R. Ç. ( 2003). System of Inspection. In A. Başaran, \& E. Bozkurt (Eds.), Problems of Structuring in Turkish National Education Inspection System (pp. 25-31). Ankara: MINPA Publishing Press.

Ecevit, H. (1996). Primary School Inspectors’ Effectiveness and Levels of Realization in Terms of Guidance and On-the-Job Training Activities in Primary Schools. Unpublished Master Thesis, Ankaral: Gazi University Institute of Social Sciences.

Ellison, G., \& Fudenberg, D. (1993). Rules of Thumb for Social Learning. Journal of Political Economy, 101, 612-643. http://dx.doi.org/10.1086/261890

Ersan, N. (1992). In-Service Training in Teacher Education and Practice in England. Unpublished Research Report, Ankaral: Gazi University Faculty of Vocational Education.

Eryılmaz, B. (1995). Public Administration. İzmir: Akademi Bookstore.

Ganis, F. (2009). “Social Learning” Buzz Masks Deeper Dimensions. Washington DC: Gilfus Education Group.

Gökçe, F. (2004). Panel of Assessment of National Education Inspection System in the Process of Access to European Union. Ankara: Minpa Printing Press.

Gözübüyük, Ş. (1998). Administrative Law. Ankara: Turhan Bookstore.

Gül, M. (2001). Instructional Leadership of Primary School Inspectors. Unpublished Master Thesis, Bursa: Orhangazi University Institute of Social Sciences.

Gümüşeli, A. İ. (1996). Instructional Leadership Behaviors of Primary School Principals in İstanbul Province. Unpublished Research, Istanbul: Y1ldı Teknik University Faculty of Arts and Sciences.

Gürsun, Y. (2007). Investigation of the Relationship between Primary School Principals’ Instructional Leadership Roles as Perceived by Teachers and Their Communication Styles. Unpublished Master Thesis, İstanbul: Yeditepe University Institute of Social Sciences.

Hobson, B. A. (1990). Teacher Perception of Evaluation as an Agent for Teacher Growth and Empowerment of Instruction. Dissertation Abstracts International.

Hodgetts, R. M. (1999). Management Theory, Process and Practice. (Translated by C. Çetin and E. C. Mutlu). Istanbul: Beta Printing Distribution Inc.

Hallinger, P., \& Joseph, F. M. (1985). Assessing Instructional Management Behaviors of Principals. The Elementary School Journal. Chicago, IL: The University of Chicago Press.

Hoy, W. K., \& Miskel, C. G. (2010). Management Theory, Research and Practice. Ankara: Nobel Printing Distribution.

Hutcheson, G., \& Sofronıu, N. (1999). The Multivariate Social Scientist. Introductory Statistics Using Generalized Linear Models. Thousand Oaks, CA: Sage Publications.

İnceler, S. (2005). Instructional Leadership Behaviors of Primary School Administrators towards Teachers' Professional Development. Unpublished Master Thesis, Bolu: Abant İzzet Baysal University Institute of Social Sciences.

Kaya, Y. K. (1986) Educational Administration. Ankara: Bilim Publications.

Kılıç, M. (1999). Primary School Inspectors' Levels of Realization regarding Their Guidance and Examination-Investigation Functions. Unpublished Master Thesis, Bolu: Abant İzzet Baysal University Institute of Social Sciences. 
Lester, P. E., \& Bishop, L. K. (2000). Handbooks of Test and Measurement in Education and Social Sciences. Maryland: London, Scarecrow Press.

Malone, Y. (2002). Social Cognitive Theory and Choice Theory. Compatibility Analysis. International Journal of Therapy, $22,10-13$.

Özer, B. (2004). In-Service Trainings of Teachers in Turkey at the Beginning of the 2000s. Journal of In-Service Education. 30, 89-100.

Özyürek, L. (1981). Effectiveness of In-Service Training for Teachers. Ankara: AÜ Faculty of Education Publications.

Patterson, F. W. (1990). A Study of the Perceptions of Teachers, Principals and Supervisors about the Ideal Practice of Instructional Supervision in the Public Schools of Tennessee. Dissertation Abstracts International.

Pilatou, V., \& Stavridou, H. (2008). A Case Study on Primary School Students’ Idea Evolution about Simple Circuit and Parallel Connection. International Journal of Learning, 15, 143-149.

Polat, E. (1997). Primary School Teachers’ Perceptions and Expectations Regarding School Principals' Instructional Leadership Roles. Unpublished Master Thesis, İzmir: Dokuz Eylül University Institute of Social Sciences.

Richardson, S. C. (1998). Actual and Ideal Role Perceptions of Instructional Supervisors in the Public School of Virginia. Dissertation Abstracts International.

Sağır, M. (2005). Perceptions of Teachers, Principals and Supervisors on Supervisors' Role of Supervision in Primary Educational Teachers' Training at Work. Unpublished Master Thesis, Bolu: Abant İzzet Baysal University.

Sağır, M., \& Memişoğlu, S. P. (2013). Levels of Encountering Problems for Primary School Administrators in Their Education Leadership Roles and The Problems Encountered. KSU Journal of Social Sciences 2, 39-56.

Sağır, M., \& Memişoğlu, S. P. (2013). The Perceptions of Administrators and Teachers on Elemantary School Administrators’ Educational Leadership Roles. Journal of Research in Education and Teaching, 2, 1-12.

Sarı, K. (1987). Sufficiency of Guidance Provided by Primary School Teachers by Çorum Province Primary School Inspectors. Unpublished Master Thesis, Ankara: Hacettepe University Institute of Social Sciences.

Seçkin, N. (1991). Role of Inspectors in Developing the Quality in Education and New Quests in Inspection. 1st Symposium of Quests for Quality Development in Education. Istanbul: College of Culture Management.

Senemoğlu, N. (2004). Development, Learning and Teaching: From Theory to Practice. Ankara: Gazi Bookstore.

Serin, M. K., \& Buluç, B. (2012). The Relationship between Leadership and Organizational Commitment in Primary Schools. Educational Administrations: Theory and Practice, 18, 435-459.

Solomonidou, C., \& Kolokotronis, D. (2008). The Role of Constructivist Educational Software on Students' Learning Regarding Mechanical Interaction. Education and Information Technologies, 13, 185-219. http://dx.doi.org/10.1007/s10639-008-9058-8

Süzeroğlu, M. A. (2006). Assessment of Primary School Principals’ Instructional Leadership Behavior. Unpublished Master Thesis, Konya: Selçuk University Institute of Social Sciences.

Taymaz A. H. (1993). Inspection. Ankara: Kadığlu Printing Press.

Taymaz, A. H. (1992). In-Service Training. Ankara: Pegem Publications.

Taymaz, A. H. (1997). Inspection in the System of Education. Ankara: TAKAV Printing Press.

Tortop, N. (1994). Personnel Management. Ankara: Yarg1 Publications.

Vriend, N. J. (2000). An Illustration of the Essential Differences between Individual and Social Learning and Its Consequences for Computational Analyses. Journal of Economic Dynamics and Control, 24, 1-19. http://dx.doi.org/10.1016/S0165-1889(98)00068-2

Yüksel, İ. (2001). Role of Primary School Inspectors in Continuous Development of Teachers. Unpublished Master Thesis, Bolu: Abant İzzet Baysal University Institute of Social Sciences. 
Scientific Research Publishing (SCIRP) is one of the largest Open Access journal publishers. It is currently publishing more than 200 open access, online, peer-reviewed journals covering a wide range of academic disciplines. SCIRP serves the worldwide academic communities and contributes to the progress and application of science with its publication.

Other selected journals from SCIRP are listed as below. Submit your manuscript to us via either submit@scirp.org or Online Submission Portal.
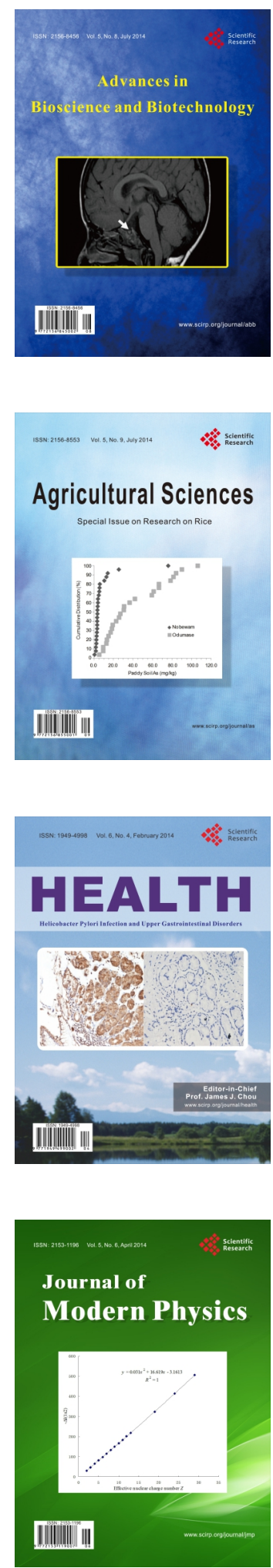
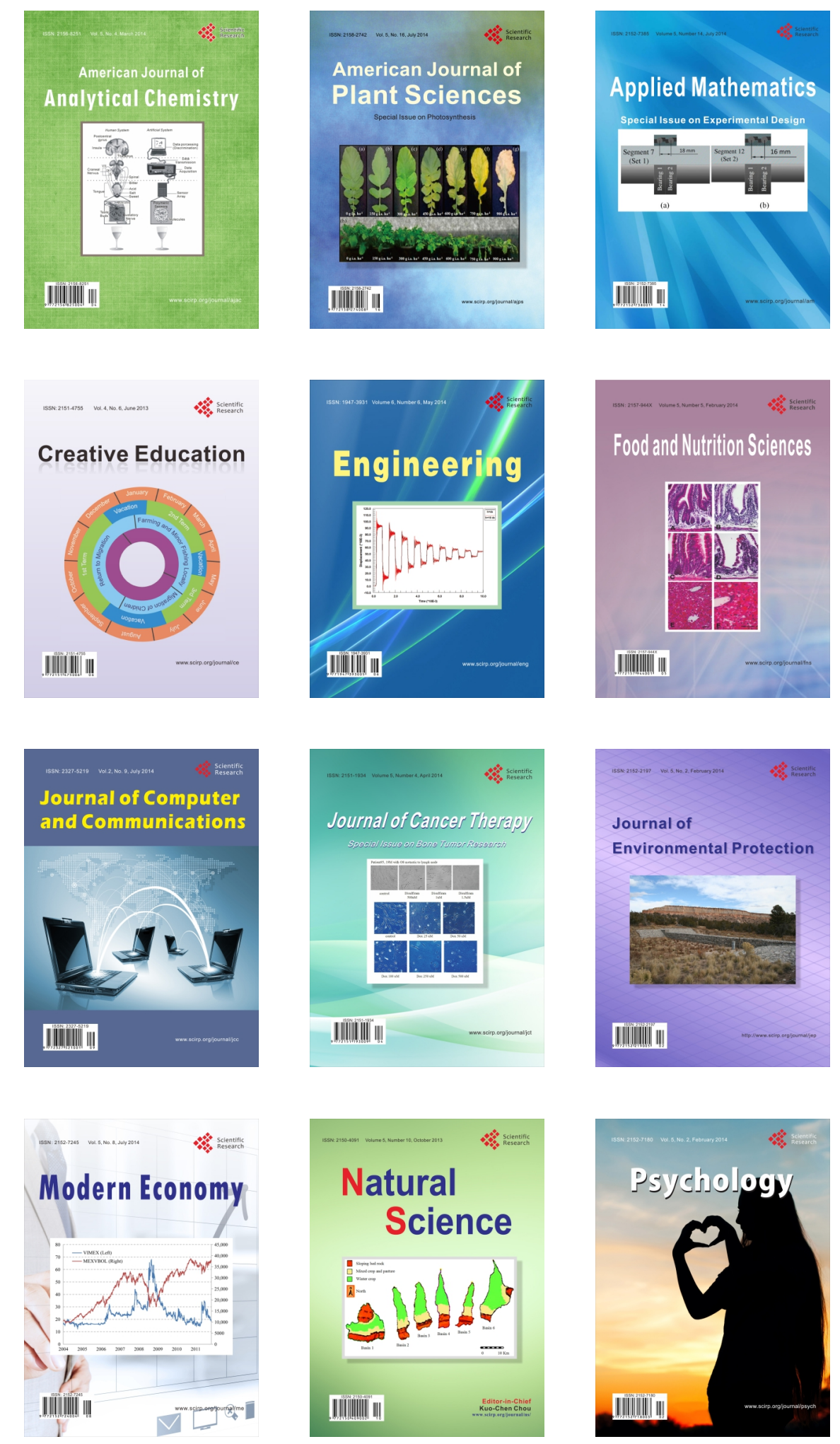